\title{
Oil Consumption in Transport and Economic Growth Nexus: Empirical Evidence from Cameroon
}

\author{
Youssouf Nvuh Njoya, PhD \\ University of Yaounde II, Cameroon \\ Mouhamed Mbouandi Njikam, PhD \\ University of Dschang, Cameroon
}

Doi:10.19044/esj.2018.v14n10p409 URL:http://dx.doi.org/10.19044/esj.2018.v14n10p409

\begin{abstract}
This paper focuses on casting light on the causal relationship between oil consumption in transport and economic growth in Cameroon. This paper uses an annual data covering the period 1975-2014, which is a five-step modern time series techniques. They include the Unit root tests, cointegration analysis, and Granger-causality based on error correction model. As a robustness test, we made use of the impulse response function and variance decomposition to portray the correlations between variables. The main result highlighted in the present paper point out the presence of a longrun equilibrium relationship between oil consumption in transport and economic growth. The error correction model shows that an estimated $1 \%$ increase in economic growth causes a rise in oil consumption in transport by $1.29 \%$ in the long run. Another results show that there exists bidirectional causality in the long-run relationship and there was no causality in the shortrun relationship at the 5\% level of significance. The decomposition of the variance and impulse response function indicates a dissymmetric of the variance of the prediction error and the dynamic properties of the system. This study provides a basis for the discussion of energy consumption in transport policies in order to maintain a sustainable economic growth in Cameroon.
\end{abstract}

Keywords: Oil consumption in transport, Economic growth, Co-integration, Causality, impulse response function, decomposition of variance

\section{Introduction}

Energy consumption is the foundation of the modern industrial economy, which greatly contributes to human and economic development. It has been the backbone for almost all economic activities for decades. The crucial role played by energy as a key driver of economic activities is well 
documented in available literature. Among the determinants of consumption, GDP is the main explanatory factor. Indeed, energy is necessary for the production and consumption of all the goods and services in industry and services. It is also essential in both countries, particularly in African countries, and Cameroon is not an exception.

Observing the evolution of the total oil consumption in Cameroon over the period 1975-2014, transport represents an average of $63 \%$ of the total consumption. Therefore, this demonstrates the importance of the transport sector.

Figure 1. Total oil consumption and oil consumption in transport from 1975 to 2014 in Cameroon

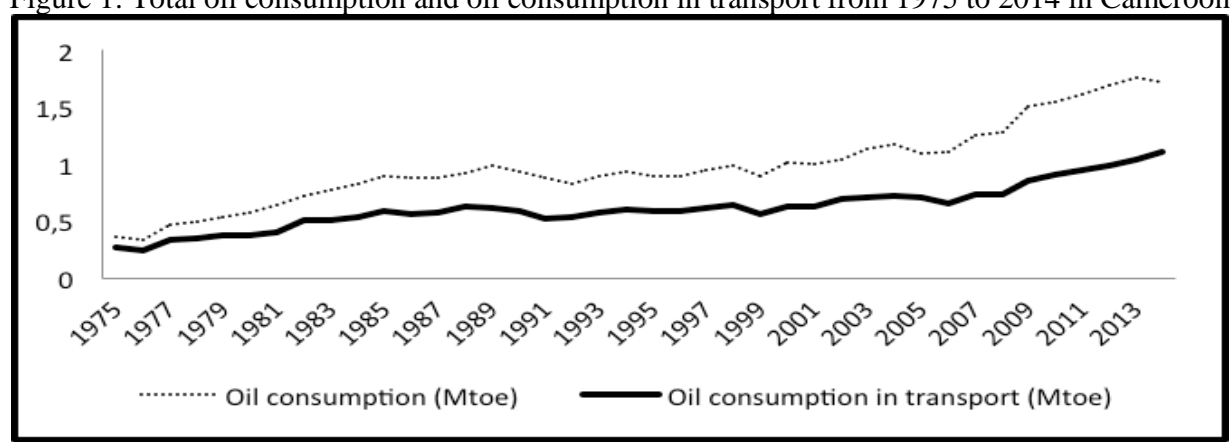

Source: Authors from IEA database

However, the transport sector heavily depends on energy. In the world today, the transportation sector represents $20 \%$ of total energy used in 2011 (US Energy Information Administration (EIA), 2015). It is the second sector after the industrial sector in regards to energy consumption. According to the IEA outlook world, energy consumption grows with the global economy. The success of the transport sector is highly dependent upon the level of energy in the economy. In fact, the transport sector can be seen as the largest user of energy in the economy (Reddy et al., 2001; Samimi, 1995). The consumption of energy is likely to grow up further due to economic growth, population growth, rapid industrialization, urbanization, and agricultural modernization (Ramanathan \& Parikh, 1999).

Figure 2. Cameroon's oil consumption in transport and GDP from 1975 to 2014

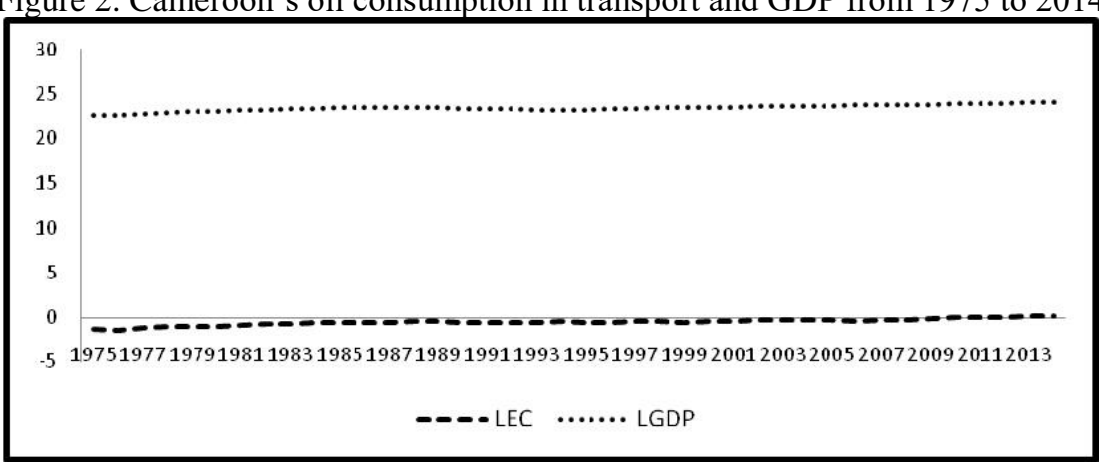

Source: Authors from IEA database and WDI database 
Figure 2 above shows the evolution of oil consumption in transport and the economic growth of Cameroon from 1975 to 2014. We can observe that these two variables show similar long-run trends characterized by upward trends, with slopes of 0.0248 for the logarithm of GDP and 0.0271 for the logarithm of oil consumption in transport. Also, there is an equilibrium relationship or plausible co-integration between these two series.

Moreover, statistical analysis confirms a strong positive correlation between oil consumption in transport and GDP (Figure 3). This correlation is not perfect, and the points on the graph do not completely align with the fitting line. However, the scatter plot is fairly flat, with the adjustment coefficient of $92.18 \%$. Furthermore, a joint analysis of the growth rates of oil consumption in transport and GDP growth shows that the two variables evolve in synchronism (Figure 4). Thus, Figure 4 shows three distinct periods. The first was from 1975-1985, which corresponds to the period when fluctuations of greater amplitudes were recorded. They are positive. Also, the fluctuations in the growth of oil consumption in transport are broader than those of economic growth. During the second period of 19861994, the fluctuations are smaller, with the particularity of being relatively negative, especially those of GDP. During the third period, 1995-2014, GDP fluctuations are positive but very flat compared to the consumption of oil in transport. This analysis may suggest that economic growth is responding to fluctuations in oil consumption in transport and vice versa. As a result, it is important to know whether oil consumption in transport cause economic growth or whether economic growth leads to more oil consumption.

Figure 3. Scatter plot between Oil consumption in transport and GDP from 1975 to 2014

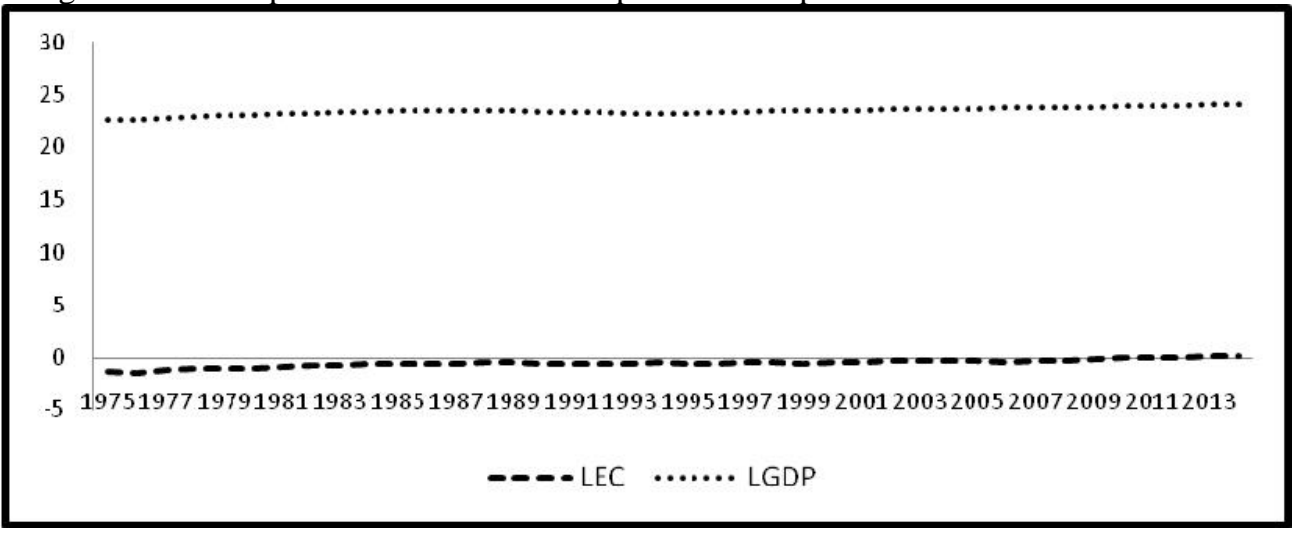

Source: Authors from IAE and WDI database 
Figure 4. Transport's oil consumption growth rate and GDP growth from 1975 to 2014

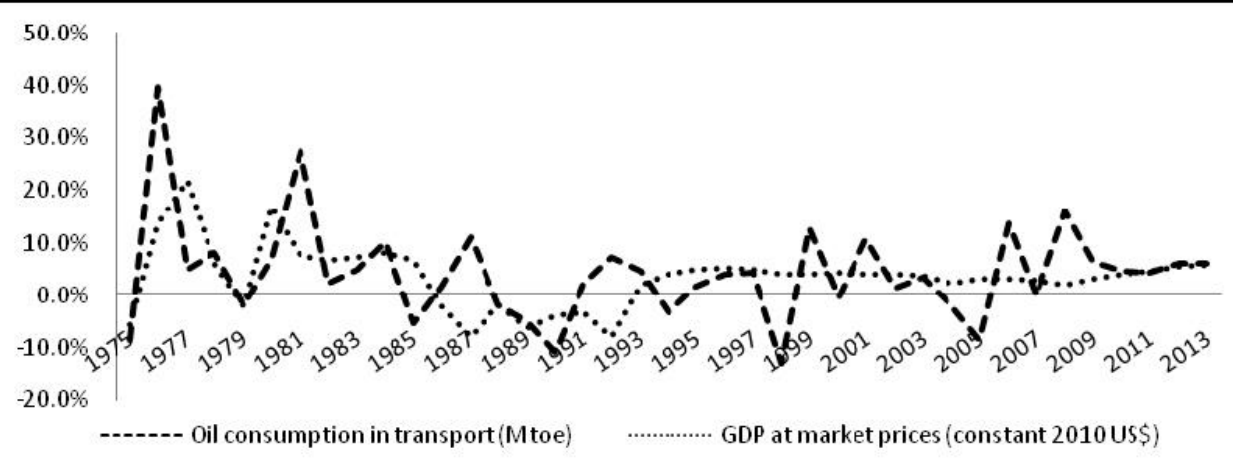

Source: Authors from IAE and WDI database

Therefore, is there any causality relationship between oil consumption in transport and economic growth in Cameroon? Specifically, does oil consumption in transport cause economic growth or do economic growth leads to more oil consumption? If it exists, is the causality unidirectional or bidirectional? However, answering these questions can help us to clearly understand the role of transportation's oil consumption in Cameroon's growth, which is meaningful for improving Cameroon's oil polices and promoting long-run growth.

The aim of this study is to demonstrate the causal empirical relationship between oil consumption in transport and economic growth in Cameroon. The paper analyzes a possible presence of a long-run equilibrium relationship between oil consumption in transport and economic growth. Compared to previous studies in this country, the essential contribution of this work is the identification of the response functions to shocks between oil consumption in transport and economic activity. Hence, this provides us with a basis for discussing oil consumption in transport policies in order to maintain a sustainable economic growth in Cameroon.

The remainder of this paper is organized as follows: Section 2 gives an overview of the Cameroon's oil consumption in transport and economic development; Section 3 provides a brief literature review on causality studies related to oil consumption and economic growth by presenting the theoretical role of transport in the economy. In Section 4, the methodology adopted in the study is presented. The data is described in Section 5. 


\section{Overview of the Cameroon's Oil Consumption in Transport and Economic Development}

Figure 5. Oil consumption in transport and GDP from 1975 to 2014

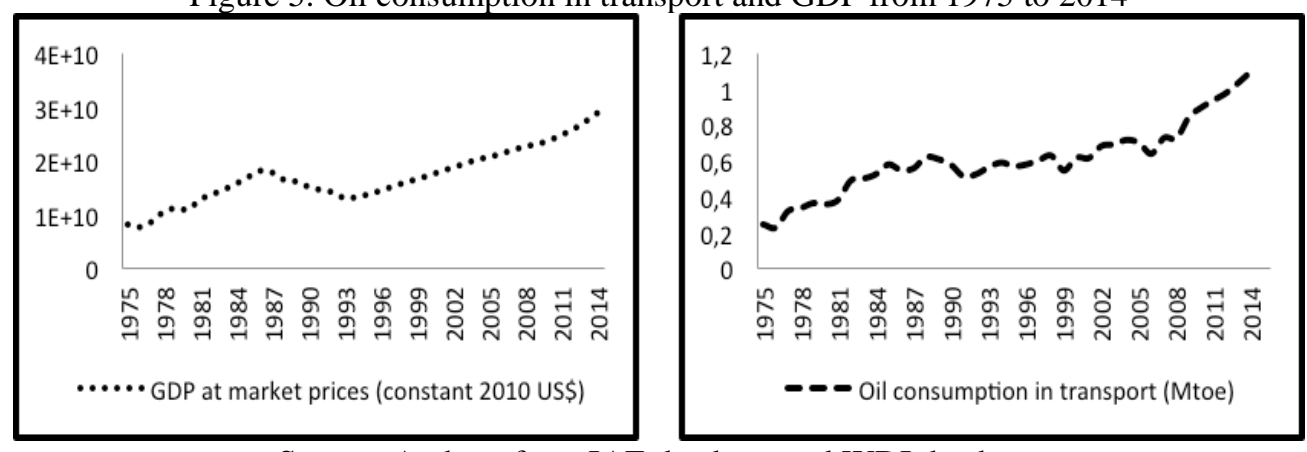

Source: Authors from IAE database and WDI database

Between 1975 and 2014, oil consumption in transport in Cameroon have quadrupled $(+334 \%)$. It rose from 0.252 million tons of oil equivalent (Mtoe) to 1.0944 Mtoe. This is the combination of population growth and transport infrastructure update. GDP over the same period tripled $(+265 \%)$. It rose from nearly 7.873 billion US dollars to nearly 28.770 billion US dollars. There were three main phases in this development. During the first phase from 1975 to 1986, the country recorded one of its best performances with an average growth rate of $8 \%$. This phase coincides with the discovery and exploitation of oil. During the second phase from 1987 to 1993 , Cameroon experienced an irregular evolution with a low level of economic activity, with an average growth rate of $-4.7 \%$. This phase corresponds to the crisis of 1987 following the oil counter-shock of 1986. As from 1988, the Structural Adjustment Plans applied until 2003. The third phase from 1994 to 2014 was marked by the resumption of economic activity with an average growth rate of $+3.9 \%$. This period was after the devaluation of the 1994 CFA franc and the end of the adjustments in 2006.

The volume of oil consumption in transport depends on the level of infrastructure. Cameroon's road infrastructure consists of over 52,000 kilometers divided into two networks: priority and non-priority. Cameroon priority roadways are not in good condition. A preliminary analysis has shown that out of the 11,120 kilometers of priority roads, only 250 kilometers are in a good state. In other words, only $2.2 \%$ of the total is in good condition, while $45 \%$ of the primary network is in an average or bad condition. It is important to note that $65 \%$ of Cameroon paved roads are more than 25 years old and the work carried out to date has been insufficient to maintain the quality of the network, which unfortunately has continued to degrade (Ministry of Public Works information system). Road transport accounts for more than $95 \%$ of petroleum products for the transport sector 
(12\% of final energy consumption). Super is only used in road transport at a rate of $59 \%$ against $41 \%$ for diesel. Apart from road transport, shipping and rail transport consume diesel in proportions of $1 \%$ and $2 \%$, respectively. Air transport consumes only jet $\mathrm{A} 1$, at a rate of $2 \%$.

Cameroon's road network is the transport backbone for Central Africa and the government has put in place a development strategy that should enable the country to create a reliable and efficient integrated infrastructure that will boost economic growth and foster sub-regional integration.

The doubling of paved roads is part of the activity of the National Council of Roads (Conaroute), which was set up in May 2005. Its mission is to facilitate the elaboration and implementation of national road policy by bringing together the elements from the public and private sector that uses Cameroon's roadways. Prospects are good for attaining this goal given that the authorities are determined to provide the country with good quality roads. From 2004-2011, the state has invested over US\$481 million, which represent an expenditure of US\$ 59.2 million a year. More than 14,000 kilometers of rural roads are in the process of rehabilitation, and we are also carrying out the progressive paving of rural roads and moderate traffic at a cost of US\$ 41.67 million. At the same time, over 900 kilometers of paved roads have been rehabilitated at a cost of US\$ 501.24 million, and another $1,500 \mathrm{~km}$ of roads have been paved at a total cost of US\$ 1.97 billion.

Cameroon has $1,008 \mathrm{~km}$ of railways, narrow gauge and singletracked line. The railway runs from the north of Cameroon to the country's economic capital, Yaoundé, and continuously extends to the west coast, the major Douala port of export.

At present, Cameroon railway system is carried out by 61 locomotives, 1,354 freight wagons and 76 passenger coaches. Freight transport comprises $90 \%$ of the rail network utilization (predominantly petroleum products, wood products and containerized traffic), which makes up approximately 1.8 million tons transport movement and about 1 million passengers transported a year.The rail network comprises of 5 major lines and serves as a vital means of economic and transport linkage between the north and south. Due to the road network, there is less development of the rail network in the north territory. Despite the fact that the main railway line between Yaounde and Douala is considered to be functioning effectively, the passenger traffic remains very few due to lots of uncontrolled competitions by many road hauliers which provide faster, more often, and eventually more attractive cost services. 


\section{Literature Review}

The empirical literature provides mixed and conflicting evidence with respect to the energy consumption-growth nexus. The result of the discrepancy is largely due to the use of different econometric methods and time periods, besides country-specific heterogeneity in climate conditions, economic development, and energy consumption patterns, among other things. From a methodological perspective, four generations of contributions can be identified. First generation studies applied a traditional vector autoregression (VAR) model based on the tradition of Sims (1972). For example, the seminar work of Kraft and Kraft (1978), using a VAR model, found evidence in favor of causality running from income to energy consumption in the United States for the period 1947-1974. Further, studies of the first generation examined the direction of causality assuming stationarity of the underlying variables (Erol \& Yu, 1987; Yu \& Choi, 1985; Abosedra \& Baghestani, 1989).

Second generation studies accounted for non-stationarity in the data and performed co-integration analysis to investigate the long-run relationship between energy consumption and growth. This second generation literature, based on the Engle and Granger (1987) two-step procedure, studied pairs of variables to check for co-integration relationships and used estimated errorcorrection models to test for Granger causality (Nachane et al., 1988; Cheng \& Lai, 1997; Glasure \& Lee, 1998). Third generation studies used multivariate estimators based on the style of Johansen (1991). Johansen's multi-variate approach also allows for more than two variables in the cointegration relationship (Masih \& Masih, 1997; Stern, 2000; AsafuAdjaye, 2000; Soytas \& Sari, 2003; Oh \& Lee, 2004). Finally, fourth generation studies employ recently developed panel-econometric methods to test for unit roots and co-integration relations. This literature estimates panelbased error-correction models to perform Granger causality tests (Lee, 2005; Al-Iriani, 2006; Mahadevan \& Asafu-Adjaye, 2007; Lee \& Chang, 2007, 2008; Apergis \& Payne, 2009; Lee \& Lee, 2010; Costantini \& Martini, 2010).

Some selected studies and their empirical setups are summarized in Table 1. Most of the studies dealing with the energy consumption-growth nexus focus on production side models, which often include capital stock and labour in addition to energy consumption and GDP. If one concentrates on energy demand, trivariate models with energy prices as an additional variable should be used (see Oh and Lee, 2004b). The studies by Masih and Masih (1998), Asafu-Adjaye (2000), Fatai et al. (2004) as well as Mahadevan and Asafu-Adjaye (2007) took the consumer price index (CPI) as a proxy of the energy price. However, as the CPI is known not to capture the energy price very well, we employ the real energy price index, such as 
that opined by Lee and Lee (2010) and Costantini and Martini (2010). Masih and Masih (1997) and Asafu-Adjaye (2000) previously used the vector errorcorrection model (VECM); Fatai et al. (2004) applied the autoregressive distributed lag (ARDL) approach; and Mahadevan and Asafu-Adjaye (2000), Lee and Lee (2010) as well as Costantini and Martini (2010) used a panel vector error-correction specification for the trivariate model.

Subsequently, few studies analyzed the relationship between energy consumption and economic growth in Cameroon. For example, Tamba et al. (2012) examined the causal relationship between diesel consumption and economic growth in Cameroon. Also, empirical results of the study confirm the presence of a long-run equilibrium relationship between diesel consumption and economic growth. The error correction model shows that an estimated $1 \%$ increase in economic growth causes a rise in diesel consumption of $1.30 \%$ in the long- run. The overall results show that there exists bidirectional causality in the long-run relationship and no causality exists in the short-run relationship between diesel consumption and economic growth at the $5 \%$ level of significance.

Table 1. Overview of selected studies

\begin{tabular}{|c|c|c|c|}
\hline Study & Method & Countries & Results \\
\hline \multirow{3}{*}{$\begin{array}{c}\text { Kraft and Kraft (1978) } \\
\text { Yu and Choi (1985) }\end{array}$} & Bivar. Sims & USA & Growth $\rightarrow$ Energy \\
\hline & Causality Bivar; & South Korea & Growth $\rightarrow$ Energy \\
\hline & Granger test & Philippines & Energy $\rightarrow$ Growth \\
\hline Erol and Yu (1987) & Bivar. Granger test & USA & Energy $\rightarrow$ Growth \\
\hline Yu and Jin (1992) & Bivar. Granger test & USA & Energy $\rightarrow$ Growth \\
\hline \multirow[t]{2}{*}{ Masih and Masih (1996) } & Trivar. VECM & Malaysia, Singapore & Energy $\rightarrow$ Growth \\
\hline & & $\begin{array}{l}\text { \& Philippines } \\
\text { India }\end{array}$ & Energy $\leftrightarrow$ Growth \\
\hline Glasure and Lee (1998) & Bivar. VECM & $\begin{array}{l}\text { Indonesia } \\
\text { Pakistan }\end{array}$ & $\begin{array}{l}\text { Energy } \rightarrow \text { Growth } \\
\text { Growth } \rightarrow\end{array}$ \\
\hline \multirow[t]{2}{*}{ Masih and Masih (1998) } & Trivar. VECM & South Korea & EnergyGrowth $\rightarrow$ \\
\hline & & \& Singapore & Energy \\
\hline Asafu-Adjaye (2000) & Trivar. VECM & $\begin{array}{l}\text { Sri Lanka \& Thailand } \\
\text { India \& Indonesia }\end{array}$ & Energy $\leftrightarrow$ Growth \\
\hline \multirow{8}{*}{$\begin{array}{c}\text { Hondroyiannis et al. (2002) } \\
\text { Soytas and Sari (2003) } \\
\text { Fatai et al. (2004) }\end{array}$} & Trivar. VECM & Thailand\&Philippines & Energy $\rightarrow$ Growth \\
\hline & Bivar. VECM & Greece & Energy $\rightarrow$ Growth \\
\hline & Bivar. VECM & Argentina & \\
\hline & Bivar. Toda and & South Korea Indonesia \& & Energy↔Growth \\
\hline & Yamamoto (1995) & Poland & Energy $\leftrightarrow$ Growth \\
\hline & & Canada, USA \& UK & Energy $\leftrightarrow$ Growth \\
\hline & & Turkey & Energy $\leftrightarrow$ Growth \\
\hline & & Indonesia \& India & Energy Growth \\
\hline \multirow{3}{*}{$\begin{array}{c}\text { Oh and Lee (2004b) } \\
\text { Wolde-Rufael (2004) }\end{array}$} & & Thailand\&Philippines & Energy $\leftrightarrow$ Growth \\
\hline & Trivar. VECM & South Korea & \\
\hline & Bivar. Toda and & Shanghai & Energy $\leftrightarrow$ Growth \\
\hline \multirow{2}{*}{ Lee (2005) } & Trivar. Panel & 18 developing nations & Growth $\leftrightarrow$ Energy \\
\hline & VECM ) & & Energy↔Growth \\
\hline
\end{tabular}




\begin{tabular}{|c|c|c|c|}
\hline Lee and Chang (2008a) & $\begin{array}{c}\text { Bivar. Panel VECM } \\
\text { Mulitv. Panel } \\
\text { VECM }\end{array}$ & $\begin{array}{c}\text { Gulf Cooperation C. } \\
16 \text { Asian countries }\end{array}$ & Energy $\leftrightarrow$ Growth \\
\hline Lee et al. (2008) & $\begin{array}{c}\text { Trivar. Panel } \\
\text { VECM }\end{array}$ & 22 OECD countries & Energy $\leftrightarrow$ Growth \\
\hline Narayan and Smyth (2008) & $\begin{array}{l}\text { Multiv. Panel } \\
\text { VECM }\end{array}$ & G7 countries & Energy $\leftrightarrow$ Growth \\
\hline Apergis and Payne (2009a) & $\begin{array}{l}\text { Multiv. Panel } \\
\text { VECM }\end{array}$ & $\begin{array}{l}11 \text { countries of the } \\
\text { Commonwealth of }\end{array}$ & Energy $\rightarrow$ Growth \\
\hline $\begin{array}{c}\text { Apergis and Payne (2009b) } \\
\text { Lee and Lee (2010) }\end{array}$ & $\begin{array}{l}\text { Multiv. Panel } \\
\text { VECM } \\
\text { Multiv. Panel }\end{array}$ & $\begin{array}{c}\text { Independent States } \\
\text { 6Central American } \\
\text { countries } \\
\text { VECM } 25 \text { OECD } \\
\text { countries }\end{array}$ & Energy $\leftrightarrow$ Growth \\
\hline
\end{tabular}

Notes: $\mathrm{X} \rightarrow \mathrm{Y}$ means variable $\mathrm{X}$ Granger-causes variable

\section{Methodology}

Using economic theory to describe the relation between the variables couldn't offer the strict definition for dynamic relation between the variables frequently. Besides, endogenous variables may also appear on both sides of an equation, which make the estimation and inference complicated. To solve these problems, we will use a vector error to analyze energy consumption and economic growth in Cameroon. This approach will be a five-step modern time series techniques: Unit root tests, co-integration analysis, and Granger-causality based on error correction model. We also use impulse response function and variance decomposition to portray the correlations between variables.

\section{Step 1:Unit Root Tests}

The first step involves applying unit root tests. According to Engle and Granger (1987), the series $x$ and y of a non-stationary linear combination with the same order of integration may be stationary. The Augmented Dickey-Fuller test (ADF) will be used to identify the presence of unit root in series. Here, we will try to test the null hypothesis that a time series is I(1) against the alternative that it is $I(0)$, assuming that the dynamics in the data have an ARMA structure. Therefore, the ADF test is based on the least squares estimation of three models (Mata, 2007): 


$$
\begin{aligned}
& \Delta x_{t}=(\rho-1) x_{t-1}+\sum_{j=2}^{k} \varphi_{j} \Delta x_{t-j+1}+\varepsilon_{t} \\
& \Delta x_{t}=(\rho-1) x_{t-1}+\sum_{j=2}^{k} \varphi_{j} \Delta x_{t-j+1}+\gamma+\varepsilon_{t} \\
& \Delta x_{t}=(\rho-1) x_{t-1}+\sum_{j=2}^{k} \varphi_{j} \Delta x_{t-j+1}+\gamma+\beta t+\varepsilon_{t}
\end{aligned}
$$

Where is the difference operator, $\mathrm{k}$ is the auto-regressive lag length, is a constant, is a coefficient on a time trend, and is a coefficient of interest. When these series are found to be non-stationary, we take the first difference and we apply the ADF tests again on the differenced data and so on.

\section{Step 2: Johansen Co-integration Tests}

The second step involves examining co-integration relationship among the variables using vector autoregressive (VAR) approach of Johansen $(1991,1988)$. The analysis of the co-integration clearly identifies the number of long-run equilibrium relationships between integrated variables of the same order. Two sets $\mathrm{x}$ and $\mathrm{y}$ are called co-integrated if they are assigned a stochastic trend of the same order of integration and/ or some linear combination of them has a lower order of integration. This test uses two statistics: statistics of the trace and the maximum eigenvalue. The asymptotic distributions of these statistics are non-standard.

\section{Step 3: Granger-Causality Test}

The third step involves building Granger-causality tests within an error correction term. At the theoretical level, co-integration implies the existence of Granger-causality between two variables. It can indicate the direction on the causality relationship. This causal relationship can be analyzed using the Granger causality test, which is based on the vector error correction model (VECM).

According to the Granger representation theorem, any co-integrated system implies the existence of an error correction mechanism that prevents the variable to deviate from their long-run equilibrium. In our case, if the three variables studied, namely: growth of GDP per capita, the logarithm of infrastructure transport, and the logarithm of energy consumption, are cointegrated, we deduce that there is an error correction mechanism.

The error correction model is a particular form of autoregressive distributed lag model (ARDL). It can be interpreted in this context as a fit model. Like the adjustment model, the coefficient of error is only relevant when it is significant and between -1 and 0 . 
Step 4: Impulse Response Function

The generalized impulse response functions trace out responsiveness of the dependent variables in the VAR to shocks to each of the variables. For each variable from each equation separately, a unit shock is applied to the error, and the effects upon the VAR system over time are noted (Brooks, 2002).

\section{Step 5: Variance Decomposition}

Variance decomposition gives the proportion of the movements in the dependent variables that are due to their "own" shocks, versus shocks to the other variables.

\section{Data Description}

This paper makes use of an annual data covering the period 1975-2014. We selected the current US dollar gross domestic product (GDP) of Cameroon in millions dollars as an indicator which measures the total economic growth. Also, it uses oil consumption in transport (EC) in millions tons of oil equivalent (Mtoe) as indicator which measures the consumption of energy in transport. GDP is adjusted at 2010's constant price according to the indices of gross domestic product. Also, GDP and EC came respectively from the World Bank indicators and International Energy Agency database from 1975 to 2014. All data are processed by logarithm (respectively LGDP for logarithm of gross domestic product and LEC for logarithm of Oil consumption of energy in transport) in order to maintain the stability of data and correct heteroscedasticity. Table 2 below presents descriptive statistics for the samples.

\begin{tabular}{ccc}
\multicolumn{4}{c}{ Table 2. Descriptive statistics over $1975-2014$} \\
\hline Variables & LEC & LGDP \\
\hline Mean & -0.556283 & 23.49474 \\
Median & -0.538493 & 23.49596 \\
Maximum & 0.090206 & 24.08261 \\
Minimum & -1.467938 & 22.73019 \\
Std. Dev. & 0.347251 & 0.323155 \\
Skewness & -0.607226 & -0.409413 \\
Kurtosis & 3.533697 & 2.917575 \\
Jarque-Bera & 2.932878 & 1.128785 \\
Probability & 0.230746 & 0.568706 \\
Sum & -22.25132 & 939.7894 \\
Sum Sq. Dev. & 4.702738 & 4.072749 \\
\hline Observations & 40 & 40 \\
\hline \multicolumn{3}{c}{} \\
\hline
\end{tabular}




\section{Empirical Results}

\subsection{Results of Unit Root Tests}

The table below presents the results of unit root test on logarithmic transformation of the levels and first differences of GDP and Oil consumption series. According to Augmented Dickey Fuller test, the null hypothesis tested in Model 3 (constant with trend) on the two series, LGDP and LEC, cannot be rejected at the \% level of significance. The trend coefficient is not rejected for LGDP and LEC series. So, we test the lagged endogenous variable coefficient. We found out that they are not rejected for the two series. Finally, Model 3 was retained by the unit root test for the two series. Stationarity is obtained by running the similar test on the first difference of the variables. This indicates that the LGDP and LEC variables are individually integrated of order one. Phillips perron and KPSS confirms that results.

\begin{tabular}{|c|c|c|c|c|c|c|c|c|}
\hline \multicolumn{9}{|c|}{ Table 3. Unit Root Test } \\
\hline & \multicolumn{3}{|c|}{$\begin{array}{c}\text { Augmented Dickey Fuller } \\
\text { (ADF) }\end{array}$} & \multicolumn{3}{|c|}{ Phillips Perron (PP) } & \multicolumn{2}{|c|}{$\begin{array}{c}\text { Kwiatkowski } \\
\text { Phillips Schmidt } \\
\text { Shin (KPSS) }\end{array}$} \\
\hline Variable & $\begin{array}{l}\text { Model } \\
1 \text { : None }\end{array}$ & $\begin{array}{c}\text { Model } \\
2 \text { : } \\
\text { Constant }\end{array}$ & $\begin{array}{c}\text { Model } \\
3 \text { : } \\
\text { Constant } \\
\text { with } \\
\text { Trend } \\
\end{array}$ & $\begin{array}{l}\text { Model } \\
1 \text { : None }\end{array}$ & $\begin{array}{c}\text { Model } \\
2 \text { : } \\
\text { Constant } \\
\text { t }\end{array}$ & $\begin{array}{c}\text { Model } \\
3 \text { : } \\
\text { Constant } \\
\text { with } \\
\text { Trend } \\
\end{array}$ & $\begin{array}{c}\text { Model } \\
2 \text { : } \\
\text { Constant } \\
\text { t }\end{array}$ & $\begin{array}{c}\text { Model } \\
\text { 3 : } \\
\text { Constant } \\
\text { with } \\
\text { Trend } \\
\end{array}$ \\
\hline LGDP & $\begin{array}{l}2.256 \\
(1)\end{array}$ & $\begin{array}{c}-2.206 \\
(1)\end{array}$ & $\begin{array}{c}-2.088 \\
(2) \\
\end{array}$ & $\begin{array}{c}2.440 \\
{[4]}\end{array}$ & $\begin{array}{c}-1.319 \\
{[4]}\end{array}$ & $\begin{array}{c}-2.047 \\
{[4]}\end{array}$ & $\begin{array}{c}0.679 * * * \\
{[5]}\end{array}$ & $\begin{array}{c}0.086 * * * \\
{[5]}\end{array}$ \\
\hline LEC & $\begin{array}{c}- \\
3.161^{* * * *} \\
(0)\end{array}$ & $\begin{array}{l}-1.565 \\
(0)\end{array}$ & $\begin{array}{l}-2.545 \\
(0)\end{array}$ & $\begin{array}{c}- \\
3.615 * * * \\
{[3]}\end{array}$ & $\begin{array}{c}-1.582 \\
{[3]}\end{array}$ & $\begin{array}{c}-2.466 \\
{[1]}\end{array}$ & $\begin{array}{c}0.718 * * * \\
{[5]}\end{array}$ & $\begin{array}{c}0.123^{* * * *} \\
{[4]}\end{array}$ \\
\hline D(LGDP) & $\begin{array}{c}- \\
3.111 * * * \\
(0)\end{array}$ & $\begin{array}{c}- \\
3.988^{* * * *} \\
(0)\end{array}$ & $\begin{array}{c}-4.047 * * \\
(0)\end{array}$ & $\begin{array}{c}- \\
3.121 * * * \\
{[2]}\end{array}$ & $\begin{array}{c}- \\
4.178 * * * \\
{[3]} \\
\end{array}$ & $\begin{array}{c}- \\
4.259 * * * \\
{[3]} \\
\end{array}$ & $\begin{array}{c}0.127 * * * \\
{[4]}\end{array}$ & $\begin{array}{c}0.118 * * * \\
{[4]}\end{array}$ \\
\hline D(LEC) & $\begin{array}{c}- \\
6.034 * * * \\
(0)\end{array}$ & $\begin{array}{c}- \\
7.376 * * * \\
(0) \\
\end{array}$ & $\begin{array}{c}- \\
7.487 * * * \\
(0) \\
\end{array}$ & $\begin{array}{c}- \\
6.114 * * * \\
{[3]}\end{array}$ & $\begin{array}{c}- \\
7.298 * * * \\
{[1]}\end{array}$ & $\begin{array}{c}- \\
7.392 * * * \\
{[1]}\end{array}$ & $\begin{array}{c}0.194 * * * \\
{[3]}\end{array}$ & $\begin{array}{c}0.162 * * * \\
{[4]}\end{array}$ \\
\hline
\end{tabular}

Note: $* * * ; * * *$ respectively denotes significant at $1 \%, 5 \%$ and $10 \%$ significance level. The figure in parenthesis () represents optimum lag length selected based on Akaike Info Criterion. The figure in bracket [] represents the Bandwidth used in the Phillips Perron and KPSS test selected based on Newey-West Bandwidth criterion.

\subsection{Results of Cointegration Tests}

After testing if the variables are stationary at first order, the next step is to estimate the VECM. Firstly, we need to select an optimum lag of VECM before performing the Johansen Cointegration test. As shown in table 4,5 and 6 , we checked the autocorrelation of the error terms in each regression by using the White heteroscedasticity test, the autocorrelation test, 
and the normality test. We concluded for joint test that error terms is free from autocorrelation problem.

Table 4. VEC Residual White Heteroscedasticity Test

\begin{tabular}{ccc}
\hline \hline Chi-sq & df & Prob. \\
\hline \hline 36.85151 & 36 & 0.4293 \\
\hline \hline
\end{tabular}

Table 5. VEC Residual Serial correlation LM

\begin{tabular}{ccc}
\hline Lags & LM-Stat & Prob \\
\hline \hline 1 & 9.101781 & 0.0586 \\
2 & 5.437321 & 0.2453 \\
3 & 4.621265 & 0.3284 \\
4 & 0.988135 & 0.9116 \\
5 & 5.720645 & 0.2210 \\
6 & 2.674226 & 0.6137 \\
7 & 2.343522 & 0.6729 \\
8 & 2.775150 & 0.5961 \\
9 & 3.093410 & 0.5423 \\
10 & 1.850112 & 0.7633 \\
11 & 1.140267 & 0.8878 \\
12 & 4.711506 & 0.3182 \\
\hline \hline
\end{tabular}

Probs from chi-square with $4 \mathrm{df}$.

Table 6. VEC Residual Normality Tests

\begin{tabular}{ccccc}
\hline Component & Skewness & Chi-sq & df & Prob. \\
\hline \hline 1 & 1.143506 & 8.063565 & 1 & 0.0045 \\
2 & -0.608807 & 2.285650 & 1 & 0.1306 \\
\hline \hline Joint & & 10.34922 & 2 & 0.0057 \\
\hline \hline Component & Kurtosis & Chi-sq & df & Prob. \\
\hline \hline 1 & 7.678219 & 33.74050 & 1 & 0.0000 \\
2 & 2.990516 & 0.000139 & 1 & 0.9906 \\
\hline \hline Joint & & 33.74064 & 2 & 0.0000 \\
\hline \hline Component & Jarque-Bera & df & Prob. & \\
\hline \hline 1 & 41.80407 & 2 & 0.0000 & \\
\hline \hline Joint & 2.285789 & 2 & 0.3189 & \\
\hline \hline
\end{tabular}


Figure 6. Correlogram of Residual Test Autocorrelations with 2 Std. Err. Bounds

$\operatorname{Cor}(\operatorname{LGDP}, \mathrm{LGDP}(-\mathrm{i}))$

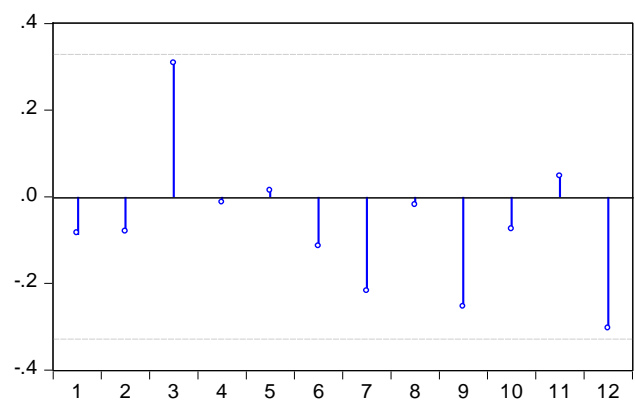

$\operatorname{Cor}(\operatorname{LEC}, \operatorname{LGDP}(-\mathrm{i}))$

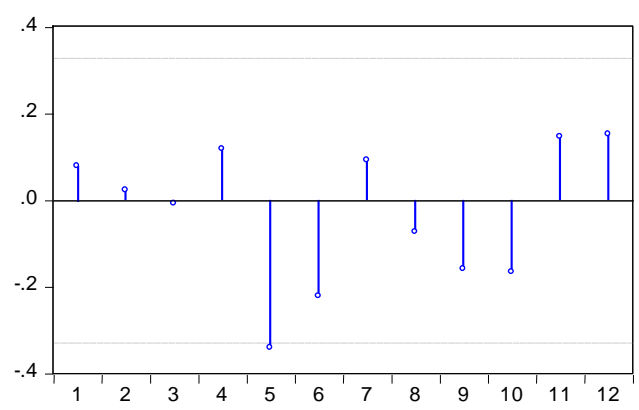

$\operatorname{Cor}(\operatorname{LGDP}, \mathrm{LEC}(-\mathrm{i}))$

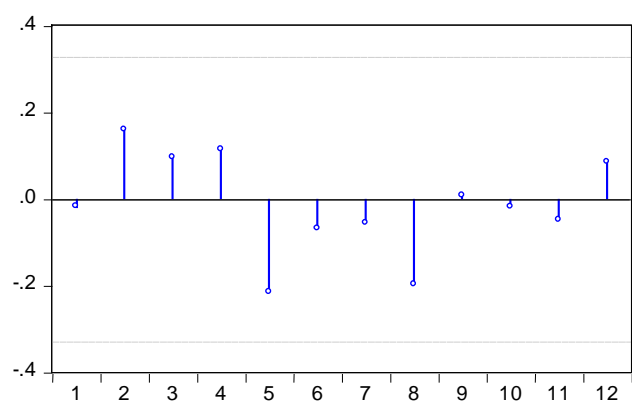

$\operatorname{Cor}(\operatorname{LEC}, \operatorname{LEC}(-\mathrm{i}))$

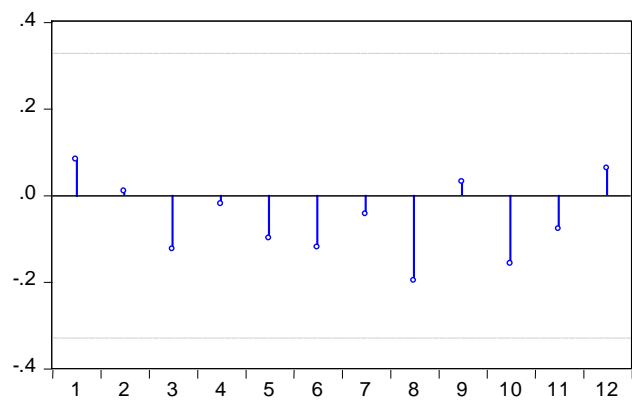

Table 7. Number of cointegration

\begin{tabular}{cccc}
\hline Trace test & Eigenvalue & Statistic & 5\% Critical Value \\
\hline None & 0.215591 & 14.22345 & 18.39771 \\
At most $1 *$ & 0.132026 & $5.238942 *$ & 3.841466 \\
\hline Maximum eigenvalue test & Eigenvalue & Statistic & 5\% Critical Value \\
\hline None & 0.215591 & 8.984510 & 17.14769 \\
At most $1^{*}$ & 0.132026 & $5.238942 *$ & 3.841466 \\
\hline
\end{tabular}

Note: $*$ denotes rejection of the hypothesis at the 0.05 level

Table 7 presents the Johansen cointegration test. The result shows that both trace test and Max Eigen test are statistically significant to reject the null hypothesis of $r \leq 1$ at 5\% significance level. Therefore, only one long run cointegration relationship exists between LGDP and LEC.

Table 8 reveals that the coefficient associated with the restoring force is negative (1.29) and significantly different from zero at the statistical threshold of $5 \%$ (student's $t$ is greater than the tabulated value). There is therefore an error-correcting mechanism. This mechanism indicates the convergence of the trajectories of LGDP series towards the long-term target. Thus, the shocks on gross domestic product in Cameroon are corrected to $1.29 \%$ by feedback effect. In other words, the long run equation revealed 
that an estimated $1 \%$ increase in economic growth causes a rise in oil consumption in transport of $1.29 \%$ at the $5 \%$ level. We found the same results as opined by Tamba et al. (2012). According to their work, they used diesel consumption while we used energy consumption in transport. It is therefore obvious that similar results will be obtained if we consider diesel as the fuel mostly used in transport in Cameroon. To provide arguments for our analysis, we plan to construct an impulse response function and a decomposition of the variance.

Table 8. Estimate of Vector error correction model

Standard errors in ( ) \& t-statistics in [ ] and D is first difference and one lag value (-1)

\begin{tabular}{|c|c|c|}
\hline CointegratingEq: & CointEq1 & \\
\hline LGDP(-1) & 1.000000 & \\
\hline $\operatorname{LEC}(-1)$ & $\begin{array}{r}-1.299662 \\
(0.28875) \\
{[-4.50099]}\end{array}$ & \\
\hline @TREND(75) & 0.008417 & \\
\hline $\mathrm{C}$ & -24.38019 & \\
\hline Error Correction: & $\mathrm{D}(\mathrm{LGDP})$ & $\mathrm{D}(\mathrm{LEC})$ \\
\hline CointEq1 & $\begin{array}{c}0.010769 \\
(0.09280) \\
{[0.11605]}\end{array}$ & $\begin{array}{r}0.374872 \\
(0.13078) \\
{[2.86634]}\end{array}$ \\
\hline $\mathrm{D}(\operatorname{LGDP}(-1))$ & $\begin{array}{c}0.446531 \\
(0.19082) \\
{[2.34009]}\end{array}$ & $\begin{array}{c}0.248264 \\
(0.26893) \\
{[0.92316]}\end{array}$ \\
\hline $\mathrm{D}(\operatorname{LGDP}(-2))$ & $\begin{array}{c}-0.134111 \\
(0.16183) \\
{[-0.82874]}\end{array}$ & $\begin{array}{r}-0.352077 \\
(0.22807) \\
{[-1.54374]}\end{array}$ \\
\hline $\mathrm{D}(\operatorname{LEC}(-1))$ & $\begin{array}{c}0.209917 \\
(0.11310) \\
{[1.85597]}\end{array}$ & $\begin{array}{c}0.043804 \\
(0.15940) \\
{[0.27480]}\end{array}$ \\
\hline $\mathrm{D}(\mathrm{LEC}(-2))$ & $\begin{array}{c}0.058749 \\
(0.10565) \\
{[0.55609]}\end{array}$ & $\begin{array}{c}0.058521 \\
(0.14889) \\
{[0.39304]}\end{array}$ \\
\hline $\mathrm{C}$ & $\begin{array}{c}0.007114 \\
(0.01991) \\
{[0.35735]}\end{array}$ & $\begin{array}{r}0.031260 \\
(0.02806) \\
{[1.11417]}\end{array}$ \\
\hline
\end{tabular}




\begin{tabular}{ccc} 
@TREND(75) & $\begin{array}{c}0.000189 \\
(0.00074)\end{array}$ & $\begin{array}{r}2.24 \mathrm{E}-05 \\
(0.00105) \\
{[0.02138]}\end{array}$ \\
\hline \hline R-squared & 0.394231 & 0.335970 \\
Adj. R-squared & 0.273077 & 0.203164 \\
Sum sq. resids & 0.065003 & 0.129111 \\
S.E. equation & 0.046548 & 0.065603 \\
F-statistic & 3.253969 & 2.529778 \\
Log likelihood & 64.86778 & 52.17223 \\
Akaike AIC & -3.127988 & -2.441742 \\
Schwarz SC & -2.823220 & -2.136974 \\
Mean dependent & 0.033072 & 0.033065 \\
S.D. dependent & 0.054596 & 0.073491 \\
\hline \hline
\end{tabular}

\subsection{Results of Granger-causality Test}

We can reject the hypothesis that LEC does not Granger cause LGDP. The $\mathrm{p}$ value is less than $5 \%$. We also can reject the hypothesis that LGDP does not Granger cause LEC. Thus, the $\mathrm{p}$ value is less than $10 \%$. Therefore, it appears that Granger causality runs two-way from LGDP to LEC and not the other way. Table 9 shows that there exists a bidirectional causality in long-run relationship and there is no causality in the short-run relationship at the 5\% level of significance. However, Table 10 shows that there is no relationship between LGDP and LEC in the short term. The Wald test is not significant. As a result, the p value is more than $10 \%$. Table 9. Pairwise Granger Causality test

\begin{tabular}{|c|c|c|c|}
\hline Null Hypothesis & Obs & F-Statistic & Prob. \\
\hline LEC does not Granger Cause LGDP & 35 & 3.56196 & $0.0150 * *$ \\
\hline LGDP does not Granger Cause LEC & & 2.11005 & $0.0991 *$ \\
\hline
\end{tabular}

Table 10. VEC Granger Causality/Block Exogeneity Wald Test

\begin{tabular}{|c|c|c|c|}
\hline \multicolumn{4}{|c|}{ VEC Granger Causality/Block Exogeneity Wald Tests } \\
\hline \multicolumn{4}{|c|}{ Included Observations: 37} \\
\hline \multicolumn{4}{|c|}{ Dependent variable: D(LGDP) } \\
\hline Excluded & Chi-sq & df & Prob. \\
\hline $\mathrm{D}(\mathrm{LEC})$ & 3.531512 & 2 & 0.1711 \\
\hline All & 3.531512 & 2 & 0.1711 \\
\hline \multicolumn{4}{|c|}{ Dependent variable: D(LEC) } \\
\hline Excluded & Chi-sq & df & Prob. \\
\hline D(LGDP) & 3.015189 & 2 & 0.2214 \\
\hline All & 3.015189 & 2 & 0.2214 \\
\hline
\end{tabular}




\subsection{Results of Variance Decomposition and Impulse Response Function (IRF)}

The result of VECM indicates the exogeneity or endogeneity of a variable in the system and the direction of Granger-causality within the sample period. However, it does not provide us with dynamic properties of the system. The analysis of the dynamic interactions among the variables in the post-sample period was conducted through variance decompositions and impulse response functions (IRFs).

Figure 7: Variance Decomposition Variance Decomposition
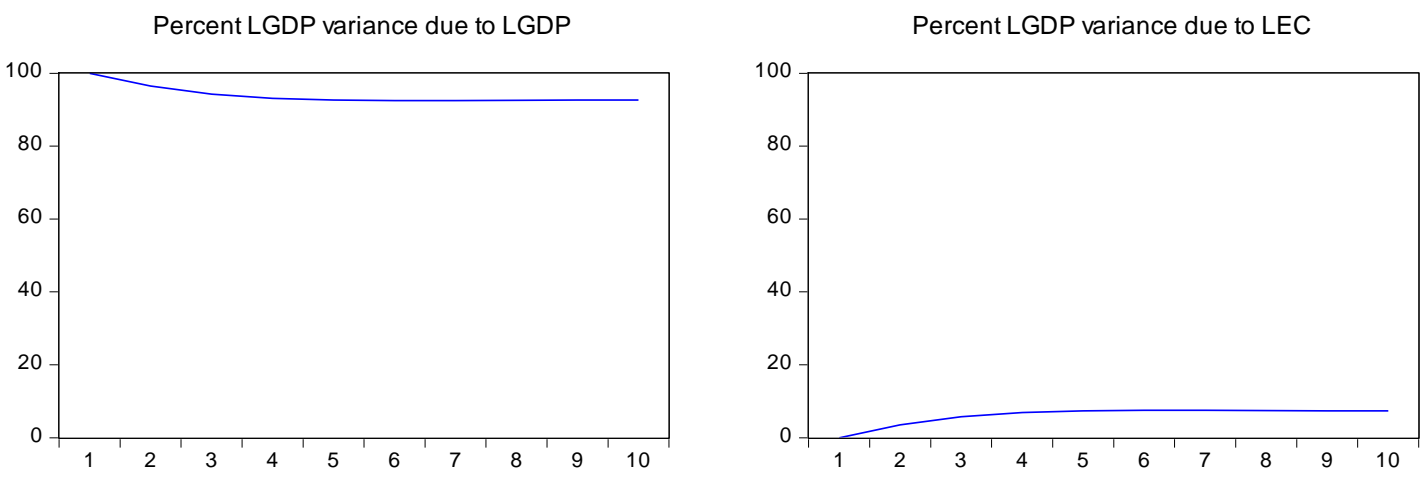

Percent LEC variance due to LGDP

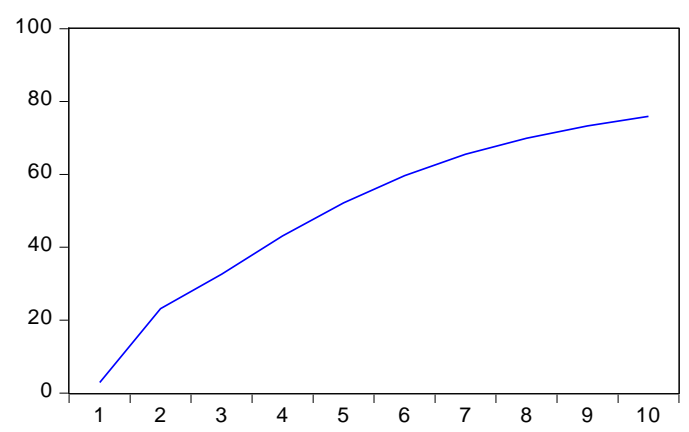

Percent LEC variance due to LEC

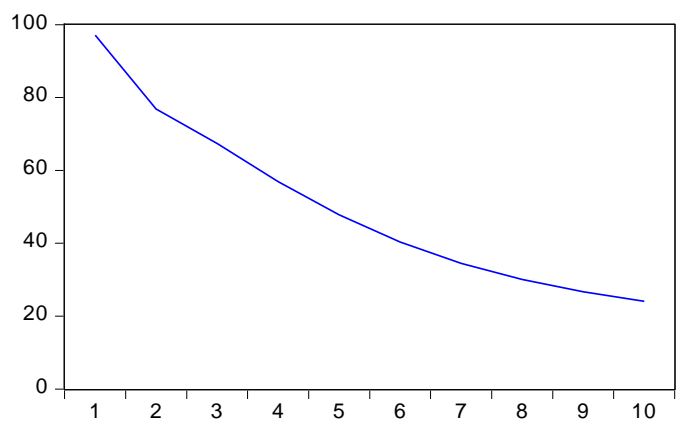

The decomposition of the variance indicates that the variance of the prediction error of LGDP is due to $92.6 \%$ of its own innovations and $7.4 \%$ of that of LEC. The variance of the prediction error of LEC is due to $76 \%$ at LGDP and 24\% at LEC. This dissymmetry confirms the result of the Granger causality test. Indeed, it has a bidirectional direction from LGDP to LEC.

The results of IRF appear in four separate tables. We analyze the response to LGDP to a shock in itself and a shock in LEC. In the same way, we also analyze the response to LEC to a shock in itself and a shock in LGDP. More interesting is how LGDP responds to shocks in the LEC, and vice versa. A shock to LEC affects LGDP for one period, but dies out very 
slowly after 10 periods. A shock to the LGDP creates a bigger response in LEC, though once again it tends to a steady state close to zero.This result confirms that an increase in the GDP growth rate will be accompanied by a rise in oil consumption in transport.

Figure 8. Impulse response function

Response to Cholesky One S.D. Innovations \pm 2 S.E.

Response of LGDP to LGDP

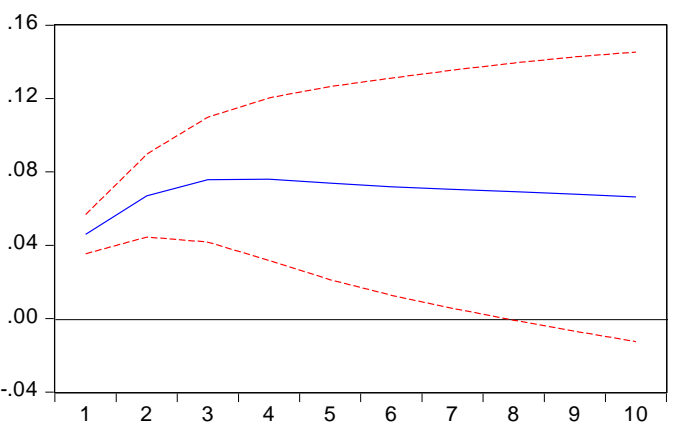

Response of LEC to LGDP

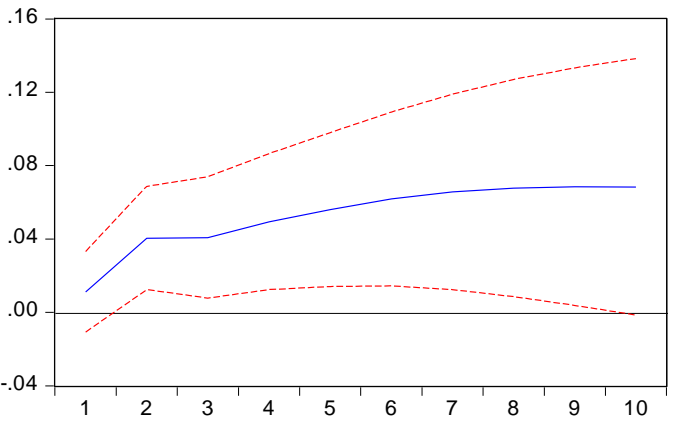

Response of LGDP to LEC

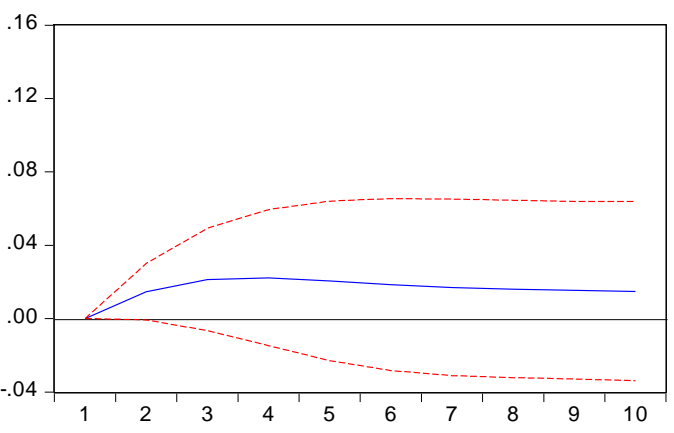

Response of LEC to LEC

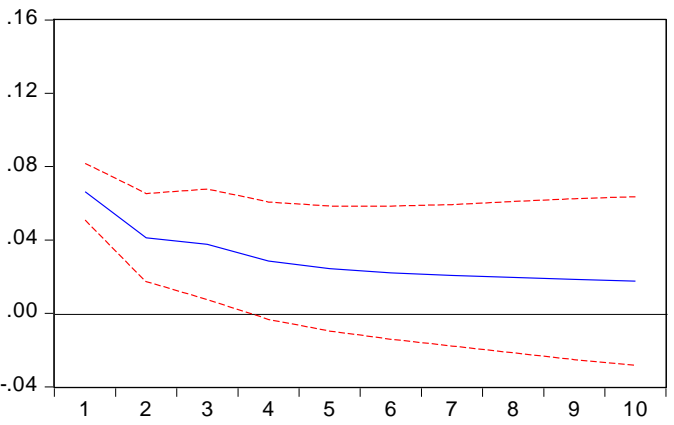

\section{Discussion and Concluding Remarks}

This paper focuses on casting light on the causal relationship between oil consumption in transport and economic growth in Cameroon. This paper uses an annual data covering the period 1975-2014, a five-step modern time series techniques. These, however, include the Unit root tests, co-integration analysis, and Granger-causality based on error correction model. As a robustness test, we have introduced the functions of impulse responses and the decomposition of the variance to portray the correlations between variables. The main result highlighted in this paper can be presented as follows:

1. We point out the presence of a long-run equilibrium relationship between oil consumption in transport and economic growth. 
2. We show that there exists bidirectional causality in long-run relationship and no causality exists in the short-run relationship at the $5 \%$ level of significance.

3. The error correction model find out that an estimated $1 \%$ increase in economic growth causes a rise in oil consumption in transport of $1.29 \%$ in the long run.

4. The decomposition of the variance indicates that the variance of the prediction error of LGDP is due to $92.6 \%$ of its own innovations and $7.4 \%$ of that of LEC. The variance of the prediction error of LEC is due to $76 \%$ at LGDP and $24 \%$ at LEC. This dissymmetry confirms the result of the Granger causality test.

5. The impulse response function confirms that a shock to LEC affects LGDP for one period, but dies out very slowly after 10 periods. While a shock to the LGDP creates a bigger response in LEC, though once again it tends to a steady state close to zero.

Overall, the results imply that oil consumption in transport stimulates economic growth; in addition, increased oil consumption in transport requires real income. In fact, the change in energy consumption following an increase in real income is greater than a change in the rate of economic growth following a change in energy consumption in transport. The low level of economic growth after a variation of oil consumption leads to the fact that there are many other factors that is contributing to economic growth, and oil consumption in transport is only one of those factors.

These findings have important implications for policy in Cameroon. As a result, the government could deal with growing oil demand by supporting oil refineries through public funded subsidies.

\section{References:}

1. Abosedra, S. \& Baghestani, H. (1989). "New evidence on the causal relationship between US energy consumption and Gross National Product" Journal of Energy Development 14, 285-292.

2. Al-Iriani, M. (2006). "Energy-GDP relationship revisited: An example from GCC countries using panel causality" Energy Policy 34 (17), 3342-3350.

3. Apergis, N. \& Payne, J. E. (2009a). "Energy consumption and economic growth: Evidence from the Commonwealth of Independent States" Energy Economics 31 (5), 641-647.

4. Apergis, N. \& Payne, J. E. (2009b). "Energy consumption and economic growth in Central America: Evidence from a panel cointegration and error correction model" Energy Economics 31 (2), 211-216. 
5. Asafu-Adjaye, J. (2000). "The relationship between energy consumption, energy prices and economic growth: Time series evidence from Asian developing countries" Energy Economics 22 (6), 615-625.

6. Cheng, B. S. \& Lai, T. W. (1997). "An investigation of co-integration and causality between energy consumption and economic activity in Taiwan" Energy Economics 19 (4), 435-444.

7. Costantini, V. \& Martini, C. (2010). "The causality between energy consumption and economic growth: A multi-sectoral analysis using non-stationary cointegrated panel data" Energy Economics 32 (3), 591-603.

8. Energy Information Administration (EIA) (2015). Annual Energy Outlook 2015. Washington D.C.

9. Engle, R. F. \& Granger, C. W. J. (1987). "Cointegration and Error Correction. Representation, Estimation, and Testing:" Econometrica, 55, 251-276.

10. Erol, U. \& Yu, E. S. H. (1987). Time series analysis of the causal relationships between U.S. energy and employment. Resources and Energy 9 (1), 75-89.

11. Fatai, K., L. Oxley, \& Scrimgeour, F. G. (2004). Modelling the causal relationship between energy consumption and GDP in New Zealand, Australia, India, Indonesia, The Philippines and Thailand. Mathematics and Computers in Simulation 64 (3-4),431- 445.

12. Glasure, Y. \& Lee, A. (1998). Cointegration, error-correction and the relationship between GDP and energy: The case of South Korea and Singapore. Resource and Energy Economics 20 (1), 17-25 Harris, R. I. D. and R. Sollis (2003). Applied time series modelling and forecasting.

13. Hondroyiannis, G., Lolos, S., \& Papapetrou, G. (2002). Energy consumption and economic growth: Assessing the evidence from Greece. Energy Economics 24, 319-336. HPSF, (2009). HPSF Statistic, Petroleum Statistic Office Study.

14. International Energy Agency Database 2016.

15. Johansen, S. (1988). "Statistical Analysis Of Cointegrating Vectors".Journal of Economic Dynamics and control, 12, 231-254.

16. Johansen, S. (1991). "Estimation and Hypothesis Testing Of Cointegration Vectors in Gaussian Vectors Autoregressive Models". Econometrica, 59, 1551-1580.

17. Kraft, J. \& Kraft, A. (1978). "On the relationship between energy and GNP” Journal of Energy and Development 3, 401-403. 
18. Lee, C. (2005). "Energy consumption and GDP in developing countries: A cointegrated panel analysis" Energy Economics 27 (3), 415-427.

19. Lee, C. \& Chang, C. (2007). "Energy consumption and GDP revisited: A panel analysis of developed and developing countries" Energy Economics 29 (6), 1206-1223.

20. Lee, C. \& Chang, C. (2008a). "Energy consumption and economic growth in Asian economies: A more comprehensive analysis using panel data" Resource and Energy Economics 30 (1), 50-65.

21. Lee, C., Chang, C., \& Chen, P. (2008b). "Energy-income causality in OECD countries revisited: The key role of capital stock" Energy Economics 30 (5), 2359-2373.

22. Lee, C. \& Lee, J. (2010). A panel data analysis of the demand for total energy and electricity in OECD countries. Energy Journal 31 (1), 1-23.

23. Mahadevan, R. \& Asafu-Adjaye, J. (2007). "Energy consumption, economic growth and prices: A reassessment using panel VECM for developed and developing countries" Energy Policy 35 (4), 24812490.

24. Masih, A. \& Masih, R. (1996). "Energy consumption, real income and temporal causality Results from a multi-country study based on cointegration and error-correction modeling techniques" Energy Economics18, 165-183.

25. Masih, A. M. M. \& Masih, R. (1997). "On the temporal causal relationship between energy consumption, real income, and prices: Some new evidence from Asian-energy dependent NICs based on a multivariate cointegration vector error-correction approach" Journal of Policy Modeling 19 (4), 417-440.

26. Nachane, D. M., Nadkarni, R. M., \& Karnik, A. V. (1988). "Cointegration and causality testing of the Energy-GDP relationship: A cross-country study" Applied Economics 20 (11), 1511-1531.

27. Narayan, P. K. \& Smyth, R. (2008). Energy consumption and real GDP in G7 countries: New evidence from panel cointegration with structural breaks. Energy Economics 30 (5), 2331-2341.

28. Oh, W. \& Lee, K. (2004a). "Causal relationship between energy consumption and GDP revisited: The case of Korea 1970-1999” Energy Economics 26 (1), 51-59

29. Oh, W. \& Lee, K. (2004b). "Energy consumption and economic growth in Korea: Testing the causality relation" Journal of Policy Modeling 26 (8-9), 973-981. 
30. Ramanathan, R. \& Parikh, J. K. (1999). "Transport Sector in India: An Analysis in the Context of Sustainable Development". Transport Policy, 6, 35-45.

31. Reddy, A. K. N., Anand, Y. P., \& D'Sa, A. (2001). "Energy for a Sustainable Road/ Rail Transport System in India". Energy for Sustainable Development, 4, 29-44.

32. Samimi, R. (1995). "Road Transport Energy Demand in Australia: A Cointegration Approach". Energy Economics, 17, 329-339.

33. Soytas, U. \& Sari, R. (2003). Energy consumption and GDP: Causality relationship in G-7 countries and emerging markets. Energy Economics 25 (1), 33-37.

34. Stern, D. I. (2000). "A multivariate cointegration analysis of the role of energy in the US macroeconomy" Energy Economics 22 (2), 267283.

35. Sims, C. A. (1972). "Money, Income and Causality", the American Economic Review, 62(4), 540-552.

36. Tamba, J. G., Njomo, D., Limanond, T., \& Ntsafack, B. (2012). "Causality analysis of Diesel Consumption and economic growth in Cameroon" Energy policy, 45, 567-575.

37. Wolde-Rufael, Y. (2004). "Disaggregated energy consumption and GDP, the experience of Shangai, 1952-1999" Energy Economics 26, 69-75.

38. World Development indicator database 2016.

39. Yu, E. \& Choi, J. (1985). "The causal relationship between energy and GNP: An international comparison" Journal of Energy and Development 10, 249-272.

40. Yu, E. \& Jin, J. (1992). "Cointegration tests of energy consumption, income and employment" Resources and Energy 14, 259-266. 